P-ISSN: 2615-1723

E-ISSN: 2615-1766

April 2018
Jurnal Riset Pendidikan Dasar

1 ( 1), ( 2018) 25-33

Submitted: Februari, Accepted: Maret, Published: April

\title{
PENINGKATAN HASILBELAJAR BAHASA INDONESIA MELALUI MODEL PEMBELAJARAN KOOPERATIF TIPE NUMBERED HEADS TOGETHER
}

\author{
Hasnah K ${ }^{1^{*}}$, Bahrum Amin ${ }^{2}$, Abdan Syakur ${ }^{3}$, Suardi $^{4}$ \\ ${ }^{1}$ Magister Pendidikan Dasar Universitas Muhammadiyah Makassar \\ ${ }^{2}$ Program Studi Pendidikan Bahasa Inggris FKIP Universitas Muhammadiyah Makassar \\ ${ }^{3}$ Program Studi Pendidikan Guru Sekolah Dasar FKIP Universitas Muhammadiyah Makassar \\ ${ }^{4}$ Program Studi Pendidikan Sosiologi FKIP Universitas Muhammadiyah Makassar \\ "Korespondensi. E-mail: Hasnahk10071987@gmail.com
}

\begin{abstract}
Abstrak
Pembelajaran bahasa Indonesia di sekolah mengindikasikan bahwa pembelajaran tersebut bersifat konvensional dan membuat fasif. Penelitian ini bertujuan untuk menganalisis penerapan pembelajaran numbered heads together (NHT) dalam meningkatkan hasil belajar dan keaktifan siswa di IV SD Inpres Barang Kecamatan Pujananting Kabupaten Barru. Menggunakan penelitian tindakan kelas (class room action research), dilaksanakan sebanyak dua siklus, tiap siklus dilaksanakan sebanyak 4 kali pertemuan. Indikator kinerja KKM 70 dengan syarat ketuntasan belajar adalah $80 \%$.Hasil perhitunganrata ketuntasan individual pada siklus I rata-rata 65,93 dan siklus II sebesar 82,53. Hasil ini menunjukkan kenaikan skor 16,6. Berdasarkan perhitungan ketuntasan klasikal, siswa yang lulus pada siklus I sebesar $53,33 \%$ dan siklus II 93,33\%, yang menunjukkan kenaikan secara signifikan sebesar $40 \%$. Kegiatan belajar berkelompok bagi siswa merupakan upaya guru dalam mengembangkan potensi kerjasama siswa, hal tersebut sejalan dengan konsep pembelajaran student centered learning.
\end{abstract}

Kata Kunci: maksimal 5 kata kunci

\section{ENHANCEMENT OF INDONESIAN LEARNING RESULTS THROUGH COOPERATIVE LEARNING MODEL TYPE NUMBERED HEADS TOGETHER}

\begin{abstract}
Indonesian language learning in schools indicates that the learning is conventional and makes it fasif. This study aims to analyze the application of numbered heads together learning (NHT) in improving student learning outcomes and activities in IV Primary Inpres of Pujananting Sub-district of Barru District. Using classroom action research, two cycles are carried out, each cycle is held for 4 meetings. Indicator of KKM 70 performance with learning completeness requirement is $80 \%$. The result of the average calculation of individual endurance in the first cycle average 65.93 and the second cycle of 82.53 . These results indicate a 16.6 increase in scores. Based on the calculation of classical completeness, students who graduated in the first cycle of $53.33 \%$ and cycle II $93.33 \%$, which showed a significant increase of $40 \%$. Group learning activities for students is an effort of teachers in developing the potential of student cooperation, it is in line with the concept of learning student centered learning.
\end{abstract}

Keywords: Numbered Heads Together, Bahasa Indonesia, Learning Outcomes.

Copyright $\odot 2018$, JRPD, ISSN 2615 - 1723 (Print), ISSN 2615 - 1766 (Online) 


\section{PENDAHULUAN}

Bahasa Indonesia merupakan salah satu cabang ilmu pengetahuan yang memegang peranan penting dalam mempercepat penguasaan ilmu pengetahuan dan teknologi. Hal ini disebabkan ilmu bahasa Indonesia merupakan sarana berpikir untuk menumbuh kembangkan cara berpikirlogis, sistematis dan kritis. Pemahaman mengenai ilmu bahasa Indonesia telah membawa manusia keperadaban modern yang tak pernah dirasakan sebelumnya.

Keberhasilan dalam proses pembelajaran bahasa Indonesia pada materi membaca cerita tidak terlepas dari kesiapan peserta didik dan kesiapan pengajar. Peserta didik dituntut mempunyai minat terhadap pelajaran bahasa Indonesia terutama pada materi membaca cerita demikian pula seorang guru dituntut menguasai materi yang akan diajarkan serta mampu memilih metode atau model pembelajaran yang tepat untuk menciptakan interaksi yang baik.

Model pembelajaran yang digunakan dalam proses pembelajaran harus dapat membuat belajar bahasa Indonesia pada materi membaca cerita terasa mudah dan menyenangkan. Pada pembelajaran bahasa Indonesia hendaknya guru mengaitkan seoptimal mungkin dengan kehidupan nyata sehingga bermakna dalam kehidupan siswa dan tidak terlalu abstrak, seorang guru juga perlu mengadakan variasi dalam kegiatan pembelajaran, memberikan kesempatan pada siswa secara mandiri dalam belajar dan berpartisipasi aktif dalam proses pembelajaran, mengadakan evaluasi dan umpan balik serta memberi penguatan pada siswa.

Pengajaran di Indonesia masih banyak menggunakan pola tradisional. Berbagai hasil penelitian menunjukkan bahwa metode ini masih dominan digunakan oleh guru (Sulfasyah, 2005; Sulfasyah, Haig \& BarrattPugh, 2015; Sulfasyah, Bahri \& Saleh, 2018). Metode tradisional yang berfokus pada guru dianggap tidak maksimal dalam mengaktifkan siswa dalam proses belajar yang dapat berdampak pada rendahnya hasil belajar mereka. Untuk mendapatkan hasil dan minat belajar yang lebih baik, diperlukan metode yang aktif, kreatif, menarik dan berfokus pada siswa.

Pembelajaran bahasa pada materi membaca cerita merupakan suatu pemberian kemampuan dan keterampilan berbahasa melalui pendidikan formal mulai dari sekolah dasar hingga ke perguruan tinggi. Pembelajaran bahasa sangat kompleks, sebab diperlukan adanya guru, kurikulum, sarana dan prasarana belajar, media pembelajaran (gambar), dan evaluasi.

Samsuri dalam Sumarni (2010:2) mengemukakan bahwa tujuan akhir pembelajaran bahasa Indonesia adalah agar siswa terampil berbahasa. Selain itu, tujuan pembelajaran bahasa Indonesia untuk mempertinggi kemahiran siswa dalam menggunakan bahasa, bukan untuk mengetahui bahasa.

Salah satu masalah pokok dalam pembelajaran pada pendidikan formal (sekolah) dewasa ini adalah rendahnya daya serap siswa. Hal ini tampak merata hasil belajar siswa yang senantiasa masih sangat memperihatinkan. Hal ini disebabkan proses pembelajaran hingga dewasa ini masih memberikan dominasi guru dan tidak memberikan akses bagi siswa untuk berkembang secara mandiri melalui penemuan dan proses berpikir.

Di pihak lain, secara empiris rendahnya kualitas hasil belajar siswa. Hal ini disebabkan proses pembelajaran yang didominasi oleh keaktifan guru dengan menggunakan metode ceramah. Sehingga Pada pembelajaran ini siswa menjadi pasif dalam pembelajaran. Meskipun demikian, guru lebih suka menerapkan metode tersebut, sebab tidak memerlukan alat dan bahan praktik, cukup

\section{Copyright $@ 2018$, JRPD, ISSN 2615 - 1723 (Print), ISSN 2615 - 1766 (Online)}


menjelaskan konsep-konsep yang ada pada buku ajar atau referensi lain.

Berdasarkan hasil observasi awal penulis, tampak bahwa fenomena pembelajaran bahasa Indonesia pada materi membaca cerita, khususnya di kelas IV tahun pelajaran 2010/2011 mengalami banyak masalah. Demikian halnya dengan hasil belajar studi bahasa Indonesia yang sangat rendah. Di antara 15 orang siswa masih ada 10 atau $66,67 \%$ siswa yang memperoleh nilai 65 ke bawah dan hanya 5 atau 33,33\% siswa yang memenuhi standar (KKM) yaitu 65 . Hal ini berarti sekitar 10 atau $66,67 \%$ orang siswa dinyatakan belum memenuhi standar nilai Kriteria Ketuntasan Minimal (KKM) untuk bidang studi bahasa Indonesia.

Masalah rendahnya hasil belajar tersebut,perlu dicarikan solusi untuk mengatasinya dengan cara menuntut guru cerdik dan inovatif dalam memilih model pembelajaran yang menyenangkan dan cocok dengan kondisi dan minat siswa. Salah satu model pembelajaran adalah model belajar kooperatif yang merupakan salah satu model belajar yang dapat mengatasi problematika dalam pembelajaran. Hal ini dinyatakan karena model pembelajaran ini menekankan pada kerja sama yang selama ini kurang terjalin dalam pembelajaran sehingga siswa tidak memiliki sikap positif dalam pembelajaran bahasa Indonesia.

Salah satu tipe model belajar kooperatif yang lebih tepat digunakan dalam meningkatkan hasil belajar bahasa Indonesia pada materi membaca cerita yaitu melalui model pembelajaran kooperatif tipe Numbered Heads Together (NHT) pada siswa kelas IV SD Inpres Barang Kecamatan Pujananting Kabupaten Barru

Mengacu pada model pembelajaran kooperatif tersebut, maka segala problematika pembelajaran selama ini dapat diselesaikan. Hal ini dinyatakan karena pada dasarnya model pembelajaran yang mengutamakan kerjasama antarindividu dan kelompok.
Dengan demikian, tidak ada siswa yang belajar sendiri-sendiri, tetapi belajar secara bermasyarakat dengan siswa lain.

$$
\text { Model pembelajaran kooperatif }
$$
tipeNumbered Heads Together (NHT) lebih mengedepankan kepada aktivitas siswa dalam mencari, mengelolah, dan melaporkan informasi dari berbagai sumber yang akhirnya untuk dipresentasikan di depan kelas. Model ini selalu di awali dengan membagi kelas ke dalam beberapa kelompok. Setiap siswa dalam kelompok sengaja diberi nomor untuk memudahkan kinerja kelompok, mengubah posisi kelompok, menyusun materi, mempresentasikan, dan mendapat tanggapan dari kelompok yang lain.

Pada dasarnya, model pembelajaran kooperatif tipe Number Head Together (NHT) efektif diterapkan dalam pembelajaran dengan materi apa pun jenisnya. Hal ini dinyatakan berdasarkan hasil pengamatan penulis terhadap konsep tipe kooperatif tersebut melalui penelitian tentang model pembelajaran kooperatif dalam pembelajaran bahasa Indonesia. Peneliti sebelumnya yang mengkaji masalah yang relevan, yakni Sumarni (2010)Peningkatan Hasil Belajar Bahasa Indonesia Melalui Metode Pembelajaran Kooperatif Tipe Number Head Together (NHT) pada Siswa Kelas IV SD No. 44 Bantaulu Kabupaen Jeneponto. Selanjutnya, Kunna (2009) meneliti dengan judul: Pemanfaatan Model Numbered Heads Together (NHT) dalam Meminimalkan Kesalahan Penggunaan Kata-Kata Baku pada Karya Tulis Ilmiah Siswa Kelas VII SMP Negeri 1 Palopo. Hasil kedua penelitian tersebut menunjukkan bahwa Model pembelajaran kooperatif tipe Numbered Heads Together (NHT) dapat meningkatkan hasil belajar bahasa Indonesia.

\section{METODE}

Penelitin ini termasuk penelitian deskriptif yang didesain melalui penelitian tindakan kelas (class room action research) yang 
bertujuan mendeskripsikan peningkatan hasil belajar bahasa Indonesia membaca cerita melalui model pembelajaran kooperatif tipe Numbered Heads Together (NHT) pada siswa kelas IV SD Inpres Barang Kecamatan Pujananting Kabupaten Barru, yang terdiri atas empat tahap yaitu (1) Perencanaan, (2) Pelaksanaan tindakan, (3) Observasi, dan (4) refleksi yang digambarkan pada Gambar 1.

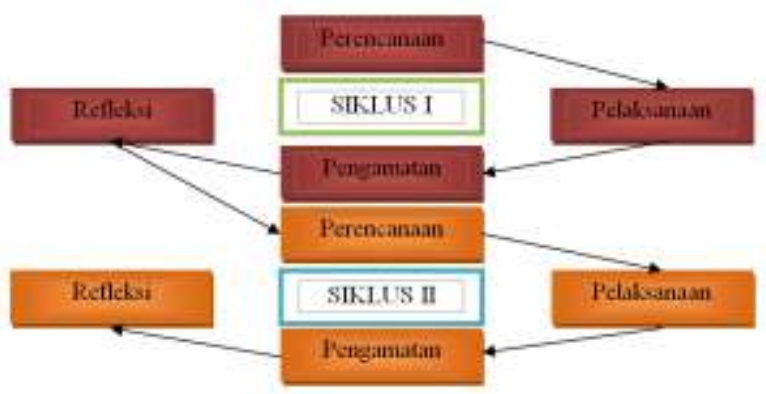

Gambar 1 Tahapan Penelitian Tindakan Kelas

Instrumen yang digunakan untuk mengumpulkan data dalam rangka penelitian ini adalah (1) Tes hasil belajar digunakan untuk memperoleh informasi tentang penguasaan siswa setelah proses pembelajaran. (2) Lembar observasi digunakan untuk mengetahui data tentang kehadiran siswa, keaktifan siswa, dan perhatian siswa dalam mengikuti proses belajar-mengajar sebagai berikut :

\begin{tabular}{|c|c|c|c|c|c|c|}
\hline \multirow[t]{2}{*}{ No. } & \multirow[t]{2}{*}{ Siswa } & \multicolumn{5}{|c|}{$\begin{array}{c}\text { Aktivitas Siswa Selama Proses } \\
\text { Belajar Mengajar }\end{array}$} \\
\hline & & $\begin{array}{lllll}1 & 2 & 3 & 4 & 5 \\
\end{array}$ & 56 & $7 a$ & $7 \mathrm{~b}$ & $7 \mathrm{cc}$ \\
\hline \multicolumn{7}{|c|}{ 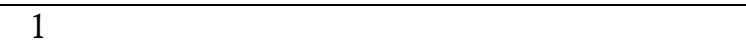 } \\
\hline \multicolumn{7}{|l|}{2} \\
\hline \multicolumn{7}{|l|}{3} \\
\hline \multicolumn{7}{|l|}{4} \\
\hline \multicolumn{7}{|l|}{5} \\
\hline \multicolumn{7}{|l|}{6} \\
\hline 7 & & & & & & \\
\hline
\end{tabular}

Keterangan: (1) Menyimak pengarahan guru, (2) Kerjasama di kelompoknya, (3) Aktif berdiskusi, (4) Mengeluarkan pendapat, (5) Mengajukan pertanyaan yang relevan, (6) Menjawab pertanyaan dengan benar dan tepat, (7) Perilaku yang tidak relevan dalam KBM (a) Membicarakan hal-hal yang tidak berhubungan dengan materi, (b) Keluar masuk kelas, (c) Bermain-main

Data yang diperoleh akan dianalisis dengan menggunakan analisis kualitatif dan kuantitatif dengan menggunakan rumus:

1. Data hasiltes

$$
\text { Nilai }=\underline{\text { Skor Jawaban Benar x } 100 \%}
$$$$
\text { Skormaksimal }
$$

2. Nilai rata-rata

$$
\text { Rata-rata }=\frac{\text { Jumlah nilai siswa }}{\text { Banyaknya siswa }}=
$$

\begin{tabular}{ccc}
\hline No. & Nilai & Kategori \\
\hline 1. & $0-34$ & Sangatrendah \\
2. & $35-54$ & Rendah \\
3. & $55-64$ & Sedang \\
4. & $65-84$ & Tinggi \\
5. & $85-100$ & Sangattinggi
\end{tabular}

Indikator kinerja dalam penelitian ini adalah digunakan skor ketercapaian dari nilai rata-rata 70-80 dengan syarat ketuntasan belajar adalah $80 \%$ sehingga penelitian ini dikatakan berhasil.

\section{HASIL DAN PEMBAHASAN}

\section{Deskripsi Siklus I}

Penelitian yang bertujuan menggambarkan peningkatan hasil belajar bahasa Indonesia membaca cerita. Siklus I dilaksanakan selama empat kali pertemuan. Pada akhir pertemuan dilaksanakan tes hasil belajar yang berbentuk ulangan harian setelah selasai penyajian materi membaca cerita Dari analisis deskriptif nilai hasil disajikan pada tabel 1 berikut:

Tabel 1 Statistik Skor Hasil Tes Siklus I

\begin{tabular}{cc}
\hline Statistik & Nilai Statistik \\
\hline Subjek & 15 \\
Skor Ideal & 100 \\
Skor Tertinggi & 95 \\
Skor Terendah & 43 \\
Rentang Skor & 52 \\
Skor Rata-rata & 65,93 \\
Standar Deviasi & 16,35 \\
\hline
\end{tabular}

Copyright $\mathbb{0} 2018$, JRPD, ISSN 2615 - 1723 (Print), ISSN 2615 - 1766 (Online) 
Apabila nilai hasil belajar bahasa Indonesia membaca cerita siswa kelas IV SD Inpres Barang Kecamatan Pujananting Kabupaten Barru dikelompokkan ke dalam lima kategori, maka diperoleh distribusi frekuensi yang ditunjukkan pada tabel 2 berikut ini

Tabel 2 Distribusi Frekuensi dan Persentase Skor Hasil Tes pada Siklus I

\begin{tabular}{cccc}
\hline $\begin{array}{c}\text { Interval } \\
\text { Skor }\end{array}$ & Kategori & Frekuensi & $\begin{array}{c}\text { Persentase } \\
(\%)\end{array}$ \\
\hline $0-34$ & Sangat & 0 & 0 \\
& Rendah & & \\
$35-54$ & Rendah & 3 & 20 \\
$55-64$ & Sedang & 4 & 26,67 \\
$65-84$ & Tinggi & 5 & 33,33 \\
$85-100$ & Sangat & 3 & 20 \\
& Tinggi & & 100 \\
Jumlah & & 15 & \\
\hline
\end{tabular}

Hasil analisis deskriptif di atas menunjukkan bahwa ketuntasan hasil belajar bahasa Indonesia melalui model pembelajaran kooperatif tipe Numbered Heads Together (NHT) siklus I dikategorikan rendah dengan nilai persentase $53,33 \%$. Dan dapat dilihat pada Gambar 1 berikut :

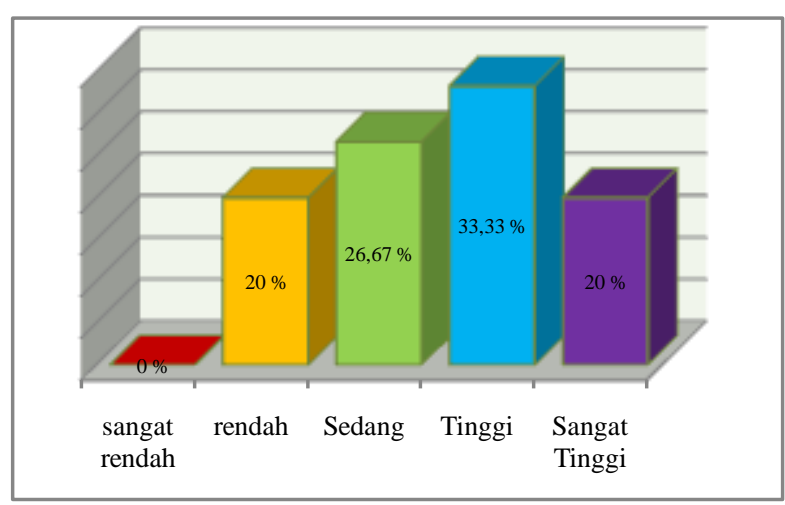

Gambar 1 Hasil Belajar SiklusI

Berdasarkan tabel 2 dan gambar 1 di atas, distribusi frekuensi, persentase, serta kategori ketercapaian ketuntasan hasil belajar bahasa Indonesia membaca cerita melalui model pembelajaran kooperatif tipe Numbered Heads Together (NHT) pada siswa kelas IV SD Inpres Barang Kecamatan Pujananting
Kabupaten Barru pada siklus I ditunjukkan pada diagram 4.2 berikut:

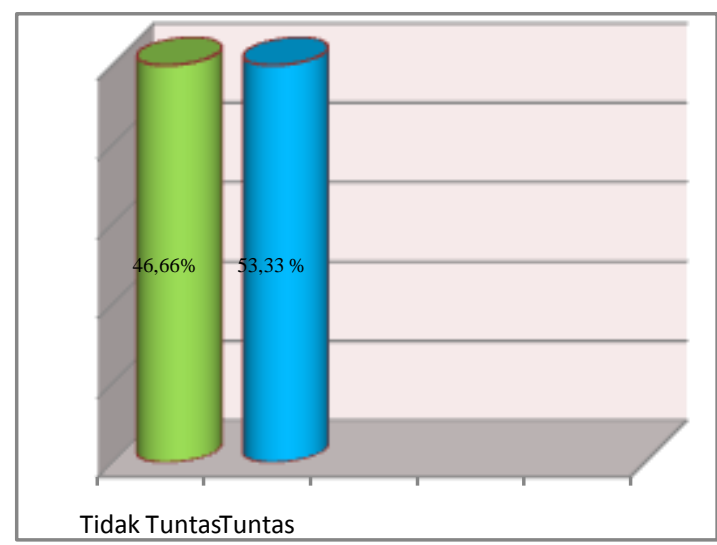

Gambar 2 Ketuntasan Hasil Belajar Siklus I

Berdasarkan kriteria hasil belajar mengenai ketuntasan kelas yaitu harus mencapai $80 \%$, data hasil penelitian pada siklus I di atas dianggap belum tuntas di mana yang tuntas dari 15 siswa hanya mencapai mencapai 53,33 \%. Penelitian ini perlu dilanjutkan pada siklus berikutnya karena berdasarkan tujuan yang ingin dicapai, yaitu peningkatan hasil belajar bahasa Indonesia membaca cerita belum terlihat.

\section{Deskripsi Siklus II}

Pada akhir pertemuan dilaksanakan tes hasil belajar yang berbentuk ulangan harian setelah selasai penyajian pembahasan membaca cerita. Dari analisis deskriptif nilai hasil belajar bahasa Indonesia melalui model pembelajaran kooperatif tipe Numbered Heads Together (NHT) Siswa Kelas IV SD Inpres Barang Kecamatan Pujananting Kabupaten Barru pada Siklus II disajikan pada Tabel 3 berikut:

Tabel 3 Statistik Skor Hasil Tes Siklus II

\begin{tabular}{cc}
\hline Statistik & Nilai Statistik \\
\hline Subjek & 15 \\
Skor Ideal & 100 \\
Skor Tertinggi & 100 \\
Skor Terendah & 60 \\
Rentang Skor & 40 \\
Skor Rata-rata & 82,53 \\
Standar Deviasi & 15,41 \\
\hline
\end{tabular}


Apabila nilai hasil belajar bahasa Indonesia membaca cerita dikelompokkan ke dalam lima kategori, maka diperoleh distribusi frekuensi yang ditunjukkan pada Tabel 4 berikut ini:

Tabel 4 Distribusi Frekuensi Siklus II

\begin{tabular}{cccc}
\hline $\begin{array}{c}\text { Interval } \\
\text { Skor }\end{array}$ & Kategori & Frekuensi & $\begin{array}{c}\text { Persentase } \\
(\%)\end{array}$ \\
\hline $0-34$ & Sangat & 0 & 0 \\
& Rendah & & \\
$35-54$ & Rendah & 0 & 0 \\
$55-64$ & Sedang & 1 & 6,66 \\
$65-84$ & Tinggi & 7 & 46,67 \\
$85-100$ & Sangat & 7 & 46,67 \\
& Tinggi & & 100 \\
Jumlah & & 15 & 100 \\
\hline
\end{tabular}

Hasil analisis deskriptif di atas menunjukkan peningkatan hasil belajar Bahasa Indonesia membaca cerita melalui model pembelajaran kooperatif tipe Numbered Heads Together (NHT) pada Siswa Kelas IV SD Inpres Barang Kecamatan Pujananting Kabupaten Barru bahwa siklus II dikategorikan sangat tinggi dengan nilai persentase $93,33 \%$, dan dapat dilihat pada Gambar 3.

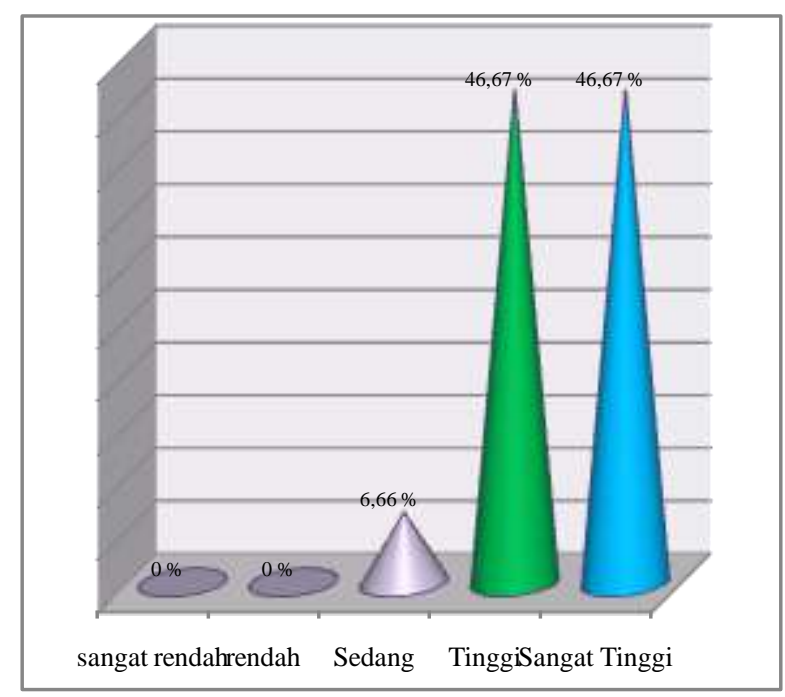

Gambar 3 Hasil Belajar Siklus II

Berdasarkan tabel 4.4. dan diagram 4.3 di atas, distribusi frekuensi, persentase, serta kategori ketercapaian ketuntasan hasil belajar siswa pada siklus II ditunjukkan pada diagram 4 berikut:

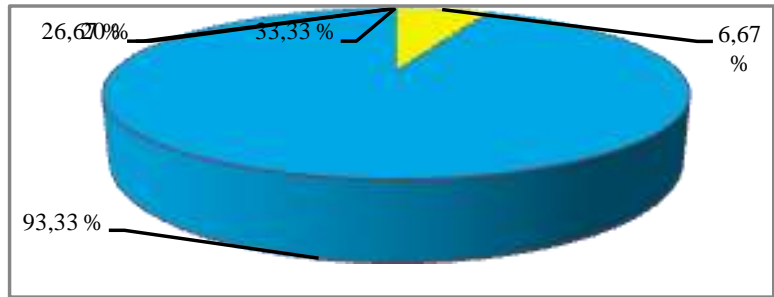

Diagram 4 Ketuntasan Hasil Belajar Siklus II

Berdasarkan kriteria hasil belajar mengenai ketuntasan kelas, yaitu $80 \%$, data hasil penelitian pada siklus dua di atas dianggap tuntas kelas di mana yang tuntas mencapai $93,33 \%$ atau 14 orang dari 15 orang siswa dan hanya 1 orang atau $6,66 \%$ siswa yang berda pada kategori tidak tuntas. Penelitian ini tidak perlu dilanjutkan pada siklus berikutnya karena berdasarkan tujuan yang ingin dicapai, yaitu peningkatan hasil belajar sudah terlihat, maka peneliti menganggap penelitian ini sudah cukup dengan menyimpulkan bahwa terjadi peningkatan hasil belajar bahasa Indonesia membaca cerita yang sangat signifikan melalui model pembelajaran kooperatif tipe Numbered Heads Together (NHT) pada siswa kelas IV SD Inpres Barang Kecamatan Pujananting Kabupaten Barru.

Berdasarkan analisis hasil belajar bahasa Indonesia membaca cerita siklus I dan siklus II perbandingan ketuntasan hasil belajar tes siklus I dan ketuntasan hasil belajar tes siklus II melalui model pembelajaran kooperatif tipe Numbered Heads Together (NHT) pada siswa kelas IV SD Inpres Barang Kecamatan Pujananting Kabupaten Barru dapat dilihat pada Gambar 5.

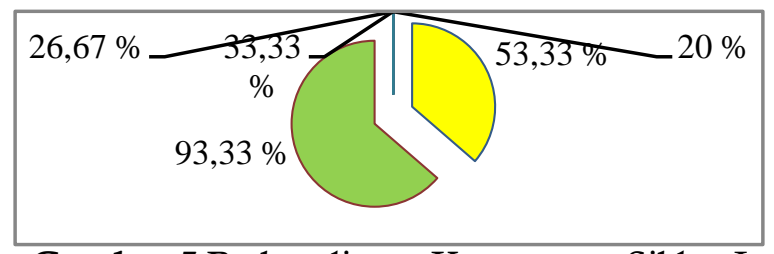

Gambar 5 PerbandinganKetuntasan Siklus I dan Siklus II 


\section{Refleksi pada Siklus I}

Pada akhir pertemuan pertama guru memberikan latihan soal mengerjakan tugas. Namun, masih banyak siswa yang tidak menyelesaikan pekerjaannya dengan berbagai alasan. Pembelajaran tahap akhir yakni memberi penghargaan kepada kelompok dan siswa yang dapat mendorong peningkatan pembelajaran. Namun, kalau dipresentasikan secara klasikal belum terlalu banyak peningkatan. Hal ini disebabkan oleh siswa belum dapat menyesuaikan secara langsung model pembelajaran yang baru diterapkan oleh guru. Faktor lain disebabkan pula oleh bimbingan bertanya jawab yang kurang menarik, sulit menciptakan pertanyaan, kegiatan belajar mengajar kurang memberikan kesempatan kepada siswa untuk memecahkan masalah sendiri, kurangnya kesempatan yang diberikan kepada siswa untuk mengembangkan pengetahuannya. Hal-hal tersebut yang dijadikan bahan pertimbangan dalam proses pembelajaran selanjutnya yaitu siklus II.

Aktivitas siswa pada siklus II sudah terlihat dengan jelas adanya keseriusan dan keantusiasan siswa dalam mengikuti pelajaran. Hal ini terlihat pada beberapa indikator mengalami peningkatan frekuensi di mana hampir semua siswa ikut terlibat di dalamnya, ini disebabkan karena minat belajar siswa.

\section{Refleksi pada Siklus II}

Siklus II dilaksanakan 4 kali pertemuan dengan menerapkan model pembelajaran kooperatif tipe Numbered Heads Together (NHT) dalam pembelajaran. Lain halnya pada siklus II kehadiran siswa hampir tidak ada yang tidak hadir mengikuti pelajaran. Hal ini disebabkan karena rasa ingin tahu siswa terhadap mata pelajaran bahasa Indonesia yang sebelumnya dianggap sulit itu ternyata mudah. Sehingga timbul semangat untuk mengikuti pelajaran. Begitu pula perhatian siswa semakin antusias dalam menerima materi pelajaran. Sehingga dapat berdiskusi dengan baik dan lancar meskipun masih ada yang mengganggu teman kelompoknya. Pada siklus II ini semangat dan minat siswa semakin meningkat dalam proses pembelajaran.

Langkah-langkahpadasiklus II ini pada dasarnya sama dengan siklus I, langkahlangkah model pembelajaran kooperatif tipe Numbered Heads Together (NHT) tetap dilaksanakan dengan melakukan beberapa pengembangan dan perbaikan masalah yang ditemukan selama proses pelaksanaan pembelajaran. Setelah merefleksi hasil tindakan pada siklus I maka dilakukan beberapa perbaikan yaitu:

1. Dilakukan penggantian kelompok, Hal ini disebabkan tidak heterogennya anggota tiap-tiap kelompok. Sehingga pada siklus II pemilihan anggota kelompok harus betul-betul heterogen dan diupayakan dalam 1 kelompok terdiri dari seorang siswa berkemampuan tinggi, sedang, dan rendah atau sangat rendah.

2. Guru berusaha lebih keras lagi dalam memberikan bimbingan kepada siswa bagaimana membaca cerita kemudian menghubungkan dengan keadaan lingkungan kehidupan mereka sehari-hari agar materi pelajaran dapat lebih mudah diingat dan lebih bermakna bagi siswa

3. Guru memulai pelajaran setelah suasana kelas betul-betul kondusif dan siswa telah siap belajar sehingga siswa lebih fokus terhadap materi yang akan dipelajari yaitu membaca cerita.

4. Guru menginstruksikan agar semua aktivitas diluar pelajaran bahasa Indonesia dihentikan terlebih dahulu dan menyiapkan segala sesuatu yang dibutuhkan pada materi yang akan dipelajari.

5. Guru lebih memotivasi siswa untuk berani mengajukan pertanyaan, memberi tanggapan serta berani tampil kedepan saat guru menyuruh untuk membaca cerita. Guru menginformasikan bahwa keberanian 
siswa merupakan salah satu aspek yang dinilai oleh guru.

6. Guru lebih mengontrol aktivitas siswa dalam pembelajaran dan berusaha semaksimal mungkin meminimalisir kegiatan siswa yang kurang positif seperti bermain, ribut, keluar masuk ruangan dan sebagainya.

7. Guru memperbanyak latihan soal dan pekerjaan rumah agar lebih memperdalam pemahaman materi membaca cerita.

Selama pelaksanan tindakan siklus II ini diperoleh beberapa kemajuan dimana keaktifan siswa semakin meningkat, baik pada saat diskusi bersama dengan anggota kelompoknya maupun saat tampil didepan kelas. Interaksi siswa maupun antara guru juga mengalami peningkatan. Mereka semakin berani dan antusias mengajukan pertanyaan, mengemukakan pendapat, menanggapi jawaban temannya dan termotivasi untuk mempresentasekan hasil kegiatan kelompoknya meskipun tanpa diminta oleh guru. Selain itu, jumlah siswa yang melakukan kegiatan lain semakin berkurang. Mereka mulai sadar bahwa tujuan bersama dapat dicapai melalui kerjasama dan partisipasi aktif dalam kelompok. Secaraumum, siswa sudah terbiasa dan semakin menyukai model pembelajaran kooperatif tipe Numbered Heads Together (NHT)Dari hasil analisis terhadap refleksi dan tanggapan siswa dapat disimpulkan hambatanhambatan dalam belajar bahasa Indonesia dengan menggunakan model pembelajaran kooperatif tipe Numbered Heads Together.

Hambatansiswadalambelajarbahasa

Indonesia denganmenggunakanmodel pembelajaran kooperatif tipe Numbered Heads Together (NHT) adalah :

a. Pemahaman siswamasih kurang dikarenakan pelajaran bahasa Indonesia di anggap pelajaran yang terrmasuk sulit.

b. Penyajian materi terlalu cepat sehingga siswa masih kurang mengerti. c. Masih kurangnya sarana dan prasarana pendukung dalam meningkatkan proses belajar mengajar.

d. Dalam proses pengajaran model pembelajaran kooperatif tipe Numbered Heads Together (NHT) membutuhkan waktu yang banyak.

Tanggapan tentang model pembelajaran kooperatif tipe Numbered Heads Together (NHT) Siswa merasa senang dengan diterapkannya model pembelajaran kooperatif tipe Numbered Heads Together (NHT) mereka merasa banyak manfaat di antaranya dengan indikator, 8 orang atau 53,33 \% mengatakan mereka terlatih untuk bekerja sama, 10 orang atau $66,66 \%$ siswa mengatakan mereka terlatih mengemukakan dan menyatukan pendapat, serta 12 orang atau $80 \%$ siswa yang mengatakan mereka terlatih untuk tampil di depan kelas, mereka juga merasa senang karena dalam belajar mereka dapat menggembangkan sendiri ide-ide mereka serta memudahkan mereka dalam memahami materi pelajaran pernyataan ini dari 13 orang atau $86,66 \%$ siswa.

\section{DAFTAR PUSTAKA}

Akarmedia, T. (2003). KamusLengkapPraktis Bahasa Indonesia. Surabaya: Akar Media

Alma, B. (2009). Guru Profesional. bandung: Alfabeta.

Arikonto, S., \& Suhardjono, S. (2010). Penelitian Tindakan Kelas. Jakarta: BumiAksara.

Djamarah, B.S., \& Zain A. (2010). Strategi Belajar Mengajar. Jakarta :RinekaCipta.

Hambali. (2007). Pengajaran Bahasa dan Sastra Indonesia. Makassar : Universitas Muhammdaiyah Makassar.

Haryono, R., \& Mahyong, M. (2007). Kamus Pintar Internasional. Jakarta: cipta media.

Ismail, L. (2010). Peningkatan Hasil Belajar Sosiologi Siswa Kelas $X$ Muallimin Muhammadiyah Makassar pada Pokok Bahasan Interaksi Sosial melalui Penerapan 
Model Pembelajaran KooperatifTife ThinkPair-Share.

Makassar:

UniversitasMuhammadiyah Makassar.

Jihat, A., \& HarisAdul. (2008). Evaluasi Pembelajaran. Yokyakarta: Multi Pressindo.

Kunna. (2009). PemanfaatanMetode Number Heads Together (NHT) dalam Meminimalkan Kesalahan Penggunaan Kata-Kata Baku pada Karya Tulis Ilmiah Siswa Kelas VII SMP Negeri 1 Palopo. Makassar : Universitas Muhammdaiyah Makassar.

Majid, A. (2006). Perencanaan Pembelajaran Mengembangkan Standar Kompetensi Guru. Bandung: PT RemajaRosdakarya.

Suryosubroto. (2002). Proses BelajarMengajar Di Sekolah. Jakarta :RinekaCipta.

Subana, dkk.(2005). Statiktik Pendidikan. Bandung :PustakaSetia.

Sumarni. (2010). Peningkatan Hasil Belajar Bahasa Indonesia Melalui Metode Pembelajaran Kooperatif Tipe Number Head Together (NHT) pada Siswa Kelas V SD No. 44 Bantaulu Kabupaen Jeneponto. Makassar : Universitas Muhammdaiyah Makassar.

Sulfasyah. (2005). The Role of instruction method on children's early writing development and knowledge of genre. Jurnal Ilmu Pendidikan, Jilid 12(3), 258270.

Sulfasyah, Haig, Y., \& Barratt-Pugh, C. (2015). Indonesian teachers' implementation of new curriculum initiatives in relation to teaching writing in lower primary school. International Journal of Education, 7(4), 53-72.

Sulfasyah, Bahri, A., \& Saleh, S.T. (2018). Writing lessons in grade 1 Indonesian thematic textbooks: A content analysis. Indonesian Journal of Applied Linguistics, Vol. 7 No. 3, January 2018, pp. 495-503.

Trianto. (2007). Model-Model Pembelajaran Inovatif Berriontasi Konstruktivistik. Jakarta: prestasi pustaka.

Trianto. (2009). Mendesain Model PembelajaranInovatif- Progresif. Komsep, Landasan, danImplementasinyaPadaKurikulum Tingkat SatuanPendidikan (KTSP)Jakarta :KencanaPrenada Media Group.

Uno B. Hamzah. (2011). Model PembelajaranMenciptakan Proses BelajarMengajar yang KreatifdanEfektif. Jakarta :BumiAksara. 